\title{
PENGGUNAAN MODEL PEMBELAJARAN EXPLICIT INSTRUCTION DENGAN TRAINER PLC UNTUK MENINGKATKAN PRESTASI BELAJAR MERAKIT SISTEM PLC
}

\author{
Suroto \\ Teknik Otomasi Industri SMK Negeri 2 Depok \\ pakroto313@gmail.com
}

\begin{abstract}
The purpose of the research was to implement the Explicit Instruction Learning Model using trainer PLC media to improve the students' learning achievement and motivation in assembling PLC system subject. The research methodology used classroom action research with XII TOI students of SMK Negeri 2 Depok as the sample. The research instruments used were formative tests and practice job sheets. The result of research showed that the average formative test in cycle I was 76,10; in cycle II was 80,32 and in cycle III was 83,77. Based on the findings, it means that the students 'scores were higher than the provided minimum requirement score after using the Explicit Instruction Model using trainer PLC media in cycle I,II and III. The students' learning motivation in cycle I, II and III were 67, 82 , and 85 respectively. It can be concluded that the students' learning motivation was improving from $(\leq 75)$ to $(\geq 75)$ at the second and third cycles.
\end{abstract}

Key Words : Explicit Instruction Model, Trainer PLC, Assembling PLC system

\begin{abstract}
ABSTRAK
Penelitian ini bertujuan Mengimplementasikan model pembelajaran explicit instruction dengan media trainer PLC untuk meningkatkan prestasi belajar dan motivasi siswa dalam mata pelajaran merakit sistem programmable logic controller. Penelitian ini menggunakan metode penelitian Tindakan Kelas (PTK) dengan sampel siswa SMK kelas XII TOI SMK Negeri 2 Depok. Instrumen yang digunakan adalah tes formatif dan lembar kerja praktikum. Hasil penelitian menunjukkan bahwa nilai rata-rata tes formatif siklus I sebesar 76,10; siklus II sebesar 80,32; dan siklus III sebesar 83,77. Nilai tersebut lebih tinggi dari KKM yang ditetapkan setelah menggunakan Model Explicit Instruction baik di silkus pertama, kedua dan ketiga. Pada siklus I juga diperoleh hasil motivasi belajar siswa bernilai 67, siklus II diperoleh nilai 82 dan siklus III diperoleh nilai 85 . Dengan demikian terjadi peningkatan motivasi belajar siswa yang semula rendah $(<75)$ pada siklus 1 meningkat menjadi tinggi(>75) pada siklus II dan siklus III.
\end{abstract}

Kata kunci: Model Explicit Instruction, Trainer PLC, Merakit Sistem PLC

\section{PENDAHULUAN}

SMK masih memerlukan media pembelajaran dalam proses kegiatan belajarmengajar teori maupun praktikum. Dengan pengembangan program studi baru di SMK Negeri 2 Depok, menyebabkan tuntutan media pembelajaran yang mengacu pada teknologi industri aplikatif sangat tinggi. Dengan melakukan perubahan program studi Elektronika Industri menjadi program studi Teknik
Otomasi Industri, pengembangan program studi yang dilakukan belum diikuti dengan pengembangan media pembelajaran yang aplikatif terhadap dunia Industri.

Perubahan program studi di SMK juga menyebabkan adanya mata pelajaran baru yang muncul sesuai acuan Spektrum SMK Pendidikan Nasional. Salah satu mata pelajaran yang ada pada program studi Teknik Otomasi Industri adalah Merakit Sistem Programmable Logic Controller (PLC) yang didalamnya 
mencakup pembelajaran secara teori dan praktik. Keterbatasan media belajar untuk mata pelajaran Merakit Sistem Programmable Logic Controller (PLC) menyebabkan tingkat nilai prestasi selama dua tahun awal dibukanya program studi ini kurang memuaskan.

Berdasarkan uraian di atas, dipandang perlu penelitian tindakan kelas dengan menerapkan model pembelajaran yang sesuai dengan karakteristik mata pelajaran adalah Merakit Sistem Programmable Logic Controller (PLC).

Model pembelajaran adalah suatu perencanaan atau suatu pola yang diguna-kan sebagai pedoman dalam merencanakan pembelajaran di kelas atau pembelajaran dalam tutorial dan untuk menentukan perangkatperangkat pembelajaran termasuk didalamnya buku-buku, film, komputer, kurikulum, dan lain-lain (Joyce dalam Trianto, 2011:5) Model pembelajaran yang tepat sangat berpengaruh dengan hasil atau output dari siswa. Model pembelajaran yang digunakan dapat disesuai kan dengan karak-teristik materi yang diajarkan. Setiap mata pembelajaran memiliki sifat maupun ciri khusus yang berbeda dengan mata pelajaran yang lainnya, sehingga perlu pemikiran yang matang untuk menerapkan model yang tepat untuk suatu kompetensi yang diajarkan,

Model Explicit Instruction merupakan salah satu model pembelajaran yang menekankan pada pendekatan guru dan siswa secara personal sehingga siswa dapat lebih mengerti tentang materi yang diajarkan dengan adanya bimbingan dariguru. Model Explicit Instruction atau model pembelajaran langsung khusus dirancang untuk mengem-bangkan belajar siswa tentang pengetahuan proseduran dan pengetahuan deklaratif yang dapat diajarkan dengan pola selangkah demi selangkah. Hal ini dapat lebih mendekatkan siswa dengan guru secara intern sehingga siswa tidak malu lagi dalam bertanya tentang hal yang belum mereka pahami.

Model pembelajaran Explicit Instruc-tion yang menyampaikan materinya bersifat algo- ritma-prosedural, langkah demi langkah sangat sesuai untuk materi pelajaran Merakit Sistem Programmable Logic Controller (PLC) yang berupa praktikum dan diharapkan dapat meningkatkan prestasi belajar siswa.

Berdasarkan uraian di atas permasalahan dalam penelitian ini dapat dirumuskan sebagai berikut: (1) Bagaimana implementasi model pembelajaran explicit instruction dengan media trainer PLC untuk meningkatkan prestasi belajar merakit sistem programmable logic controller pada siswa kelas XII Teknik Otomasi Industri di SMKN 2 Depok Sleman? (2) Bagaimana prestasi belajar siswa yang mengikuti model pembelajaran Explicit Instruction dengan media "Trainer PLC" pada mata pelajaran merakit sistem programmable logic controller dengan media pembelajaran Kelas XII Teknik Otomasi Industri Tahun Pelajaran 2013/2014 di SMKN 2 Depok Sleman? (3) Bagaimana motivasi belajar siswa yang mengikuti model pembelajaran Explicit Instruction dengan media "Trainer PLC" pada mata pelajaran merakit sistem programmable logic controller dengan media pembelajaran Kelas XII Teknik Otomasi Industri Tahun Pelajaran 2013/2014 di SMKN 2 Depok Sleman? Tujuan dari penelitian ini adalah mengimplementasikan model pembelajaran explicit instruction dengan media trainer PLC untuk meningkatkan prestasi belajar dan motivasi merakit sistem programmable logic controller pada siswa kelas XII Teknik Otomasi Industri di SMK N 2 Depok Sleman dan Meningkatkan prestasi belajar siswa standar kompetensi merakit sistem pro-grammable logic controller dengan penggu-naan model pembelajaran explicit instruction dengan media Trainer PLC siswa kelas XII Teknik Otomasi Industri Tahun Pelajaran 2013/2014 di SMK N 2 Depok Sleman. Dalam penelitian ini disusun hipotesis tindakan yang akan diuji kebenarannya. Hipotesis yang diuji kebenarannya pada penelitian ini adalah Siswa dapat meningkat prestasi belajarnya sehingga memenuhi nilai KKM yang sudah ditetapkan setelah menggunakan Model Pembelajaran 
Explicit Instruction pada standar kompetensi merakit sistem programmable logic controller.

Model Pembelajaran Explicit Instruction merupakan model pembelajaran secara langsung khusus dirancang untuk mengem-bangkan belajar siswa tentang pengetahuan procedural dan pengetahuan deklaratif yang dapat diajarkan dengan pola selangkah demi selangkah. Jadi model pembelajaran ini sangat cocok diterapkan dikelas dalam materi tertentu yang bersifat dalill pengetahuan agar proses berpikir siswa dapat mempunyai keterampilan procedural dan semua siswa aktif terlibat.

Model ini pertama kali diperkenalkan oleh Rosenshine dan Steven pada tahun 1986. Arends (2001) menyebutkan teori yang melandasi model ini yaitu teori behavioral, penelitian aktifitas guru, teori belajar social.

Langkah-langkah model pembelajaran Explicit Instruction adalah sebagai berikut: (1) Guru menyampaikan tujuan dan menyiapkan siswa., (2) Guru mendemonstrasikan pengetahuan dan ketrampilan. (3) Guru membimbing murid dalam pelatihan, (3)Guru mengecek pemahaman dan memberikan umpan balik. (4) Guru memberikan kesempatan untuk latihan lanjutan.

Model pembelajaran Explicit Instruction adalah jenis model pembelajaran yang sangat cocok diterapkan pada standar kompetensi merakit sistem programmable logic controller (PLC).

Trainer PLC adalah gabungan dari central control unit (CCU), piranti input dan output (internal dan eksternal), unit power supply dan aktuator yang telah dirakit menjadi satu yang dapat difungsikan menjadi sebuah instrument kendali. Banyak tipe Trainer PLC yang dibuat, disesuaikan dengan kebutuhan kerja yang akan dilakukan. Seperti PLC Omron, Festo, Siemens, Zelio dan lain-lain. Dalam melakukan pengendalian/pengontrolan dengan Trainer PLC dapat dilakukan dengan beberapa bahasa pemrograman seperti Ladder Diagram, Statement List, Function Blok dan lain sebagainya.

\section{Pendidikan Ke juruan}

Berdasarkan UU Nomor 20 Tahun 2003

Pasal 15, pendidikan kejuruan merupakan pendidikan menengah yang mempersiapkan peserta didik terutama untuk bekerja dalam bidang tertentu. Pendidikan kejuruan berperan menyiapkan peserta didiknya untuk siap memasuki dunia kerja dengan berbekal ilmu pengetahuan dan keahlian serta dapat mengembangkan diri dan kemampuannya sesuai dengan perkembangan ilmu pengetahuan dan teknologi yang terjadi.

Pendidikan Menengah Kejuruan bertujuan untuk meningkatkan kecerdasan, pengetahuan, kepribadian, akhlak mulia, serta keterampilan untuk hidup mandiri dan mengikuti pendidikan lebih lanjut sesuai dengan kejuruannya (Dirjenmandikdasmen, 2006: 2). Pendidikan menengah kejuruan mengutamakan penyiapan siswa untuk memasuki lapangan kerja serta mengembangkan sikap profesional serta membentuk dan mengembangkan kemampuan dan kompetensi siswa yang meliputi kemampuan kognitif, afektif, dan psikomotorik.

Proses belajar-mengajar biasa disebut sebgai proses pengajaran, yang merupakan suatu kegiatan melaksanakan kurikulum suatu lembaga pendidikan, agar dapat mempe-ngaruhi para siswa mencapai tujuan pendidikan yang telah ditetapkan. Tujuan pendidikan pada dasarnya mengantarkan para siswa menuju pada perubahan-perubahan tingkah laku baik intelektual, moral maupun sosial agar dapat hidup mandiri sebagai individu dan makhluk sosial. Dalam mencapai tujuan tersebut siswa berinteraksi dengan lingkungan belajar yang diatur guru melalui proses pengajaran.

Prestasi dalam Kamus Umum Bahasa Indonesia yang disusun oleh Poerwodarminto (1995), yang dimaksud prestasi adalah hasil yang telah dicapai dari yang telah dilakukan, dikerjakan, dan sebagainya. Prestasi menunjukkan suatu keberhasilan yang diperoleh berdasarkan aktivitas/ kegiatan yang telah dilakukan. Dengan demikian prestasi menunjukkan hasil penilaian tentang kecakapan 
seseorang setelah berusaha. Prestasi seseorang sangat berkaitan dengan kemampuannya, semakin baik kemampuan seseorang maka semakin tinggi pula prestasi orang tersebut.

Prestasi belajar dalam Kamus Umum Bahasa Indonesia adalah penguasaan pengetahuan atau ketrampilan yang dikembangkan oleh mata pelajaran lazimnya ditunjukkan dengan nilai tes atau angka yang diberikan oleh pendidik (Poerwodarminto,1995). Presta-si belajar merupakan hasil dari sebuah evalua-si yang telah dilakukan, evaluasi dilakukan untuk meneliti hasil dan proses belajar peserta didik serta untuk mengetahui kesulitan-kesulitan yang melekat pada proses belajar (Slameto, 1995: 51). Evaluasi prestasi belajar dapat dilakukan dalam beberapa ragam, menurut Muhibbin Syah (1995: 143- 144) salah satunya adalah post test. Post test merupakan kegiatan evaluasi yang dilakukan pendidik pada setiap akhir penyajian materi.
Evaluasi ini berlangsung singkat dan cukup dengan menggunakan instrumen sederhana yang berisi item-item yang jumlahnya terbatas. Berdasarkan pendapat di atas maka prestasi belajar dapat diartikan sebagai tingkat kemampuan peserta didik diukur dari penguasaan pengetahuan, kemampuan, kebiasaan dan keterampilan serta sikap sebagai hasil proses belajar di sekolah yang dilaporkan berupa buku rapor peserta didik.

\section{METODE}

Metode penelitian yang digunakan adalah metode Penelitian Tindakan Kelas atau Classroom Action Research. Penelitian dilaksanakan di SMK Negeri 2 Depok dengan subyek penelitian kelas XII-TOI sebanyak 31 orang siswa. Prosedur penelitian ini disusun dalam bagan alur seperti di bawah ini.

\section{Gambar 1. Alur PTK Menggunakan Model Explicit Instruction}

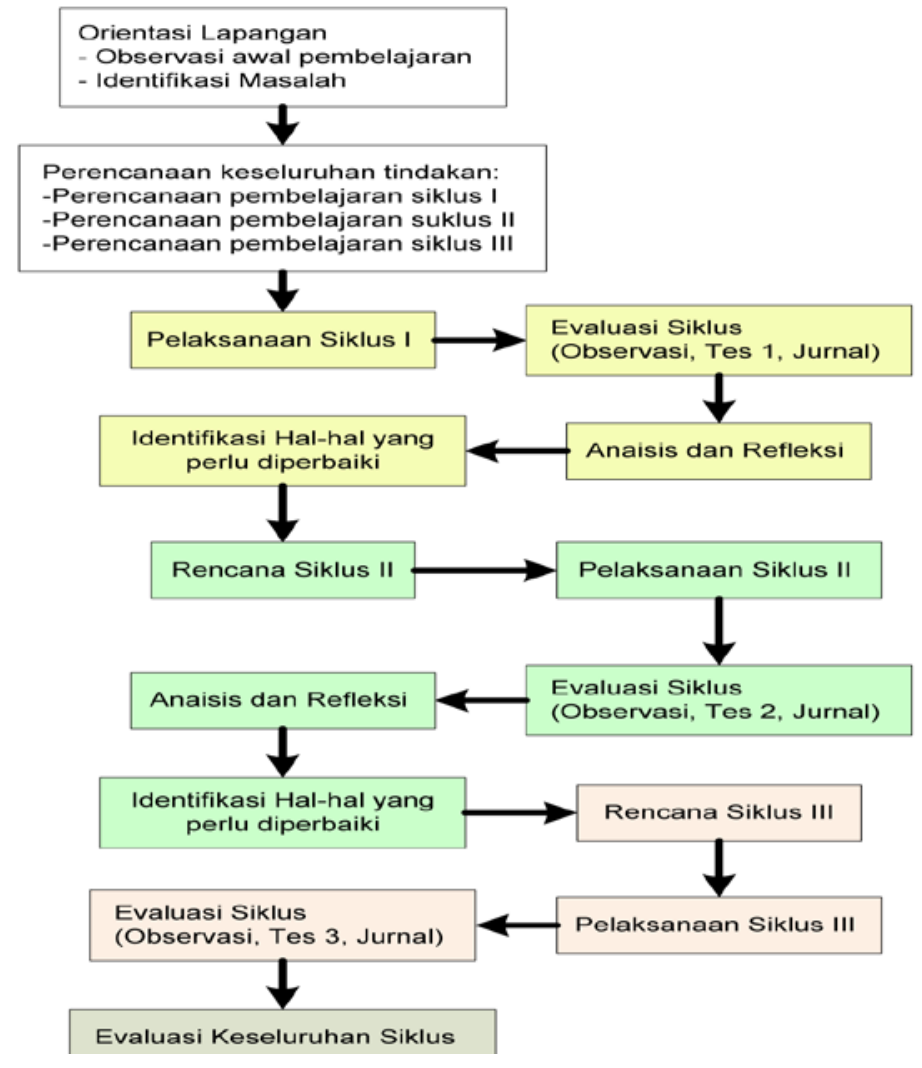

Berdasarkan bagan di atas prosedur yang ditempuh dalam penelitian ini adalah (1) orientasi atau Observasi Awal yaitu hasil dari kegiatan ini dijadikan sebagai dasar pemikiran 
untuk melakukan penelitian tindakan kelas dan sebagai langkah awal untuk merumuskan perencanaan tindakan yang akan dilakukan. (2) perencanaan Tindakan yaitu Merancang Rencana Pelaksanaan Pembelajaran (RPP) untuk masing -masing siklus, membuat bahan ajar meliputi media pembelajaran dan Lembar Kerja Siswa (LKS) yang akan digunakan pada proses pembelajaran tiap siklus. (3) pembuatan soal tes formatif per siklus untuk melihat ketercapaian nilai KKM siswa. (4) pembuatan format observasi, wawancara dan angket utuk guru dan siswa, dan (5) uji coba instrumen tes kepada siswa kelas XII dan penetapan kelas yang akan dijadikan sebagai subjek penelitian.

Penelitian ini dilaksanakan sebanyak tiga siklus dengan mengambil Kompetensi Dasar (KD) Merakit Sistem Kendali Berbasis PLC. Adapun langkah-langkah penelitian yang dilakukan peneliti tiap siklus adalah sebagai berikut: (1) tindakan pembelajaran siklus I yaitu pembelajaran Merakit Sistem PLC untuk keperluan otomasi industri menggunakan model Explicit Instruction dengan materi pokok Sistem Kendali Motor Berurutan Berbasis PLC dilanjutkan mengisi tes I dan jurnal pembelajaran harian. Peneliti menganalisis dan merefleksi hasil tindakan siklus I sebagai bahan pertimbangan untuk pelaksanaan tindakan siklus II. (2) tindakan pembelajaran siklus II yaitu pembelajaran Merakit Sistem PLC untuk keperluan otomasi industri menggunakan modell Explicit Instruction dengan materi pokok Sistem Kendali Motor Reverse-Forward Berbasis PLC. Dilanjutkan mengisi tes formatif II dan jurnal pembelajaran harian. Peneliti menganalisis dan merefleksi hasil tindakan siklus II sebagai bahan pertimbangan untuk pelaksanaan tindakan siklus III, (3) tindakan pembelajaran siklus III yaitu pembelajaran Merakit Sistem PLC Untuk Keperluan Otomasi Industri menggunakan model Explicit Instruction dengan materi pokok Sistem Kendali Motor Star-Delta Berbasis PLC. Dilanjutkan mengisi tes formatif II dan jurnal pembelajaran harian. Peneliti menganalisis dan merefleksi hasil tindakan siklus III. Setelah ketiga siklus selesai dilaksanakan pengisian angket oleh siswa dan wawancara kepada siswa terhadap pembelajaran Merakit Sistem PLC Untuk Keperluan Otomasi Industri yang sudah dilaksanakan dengan menggunakan model Explicit Instruction.

Analisis data hasil tes formatif dari setiap siklus tindakan pembelajaran yang telah dilakukan dihitung jumlah dan rata-ratanya. Penghitungan jumlah dan rata-rata digunakan untuk melihat perbedaan hasil belajar siswa antara siklus pembelajaran I, II, dan III. Adapun rumus penghitungan jumlah dan rata-rata sebagai berikut:

$$
\sum X=X 1+X 2+X 3+\cdots+X n
$$

$\sum X=$ Jumlah Total

$\mathrm{X}=$ Nilai Siswa

$\mathrm{Xn}=$ Nilai Siswa Ke-

$\bar{X}=\frac{X 1+X 2+X 3+\cdots+X n}{n}$

$\overline{\mathrm{X}} \quad=$ Nilai Rata-rata

$\mathrm{X} \quad=$ Nilai Siswa

$\mathrm{Xn}=$ Nilai Siswa Ke-

$n=$ Jumlah Siswa

Analisi terhadap angket motivasi belajar menggunakan rumus sebagai berikut:

SI $\quad=$ TS $/ \mathrm{SM} \times 100 \%$

$\mathrm{NR} \quad=\mathrm{TSK}: \mathrm{N}$

Keterangan:

SI $\quad=$ Skor Individu

TS $=$ Total Skor

SM $=$ Skor Maksimum

NR = Nilai Rata-rata Siswa

TSK $=$ Total Skor Kelas

$\mathrm{N}=$ Jumlah Siswa 


\section{Krite ria Ke be rhasilan}

- Seorang siswa dikatakan tuntas belajar jika menguasai bahan (ketercapaian belajarnya) $\geq 77 \%$. (KKM SMK Negeri 2 Depok Sleman tahun ajaran 2013/2014).

- Seorang siswa dikatakan tidak tuntas belajar jika menguasai bahan (ketercapaian belajarnya) $\leq 77 \%$. (KKM SMK Negeri 2 Depok Sleman tahun ajaran 2013/2014).
- Motivasi belajar siswa dikatakan tinggi apabila sebagian besar siswa senang/setuju dengan penggunaan model pembelajaran explicit instruction ( Nana, 1997:76 ).

\section{HASIL DAN PEMBAHASAN}

\section{Hasil Belajar Merakit Sistem}

Hasil Perhitungan rata-rata tiap-tiap siklus disajikan dalam diagram sebagai berikut :

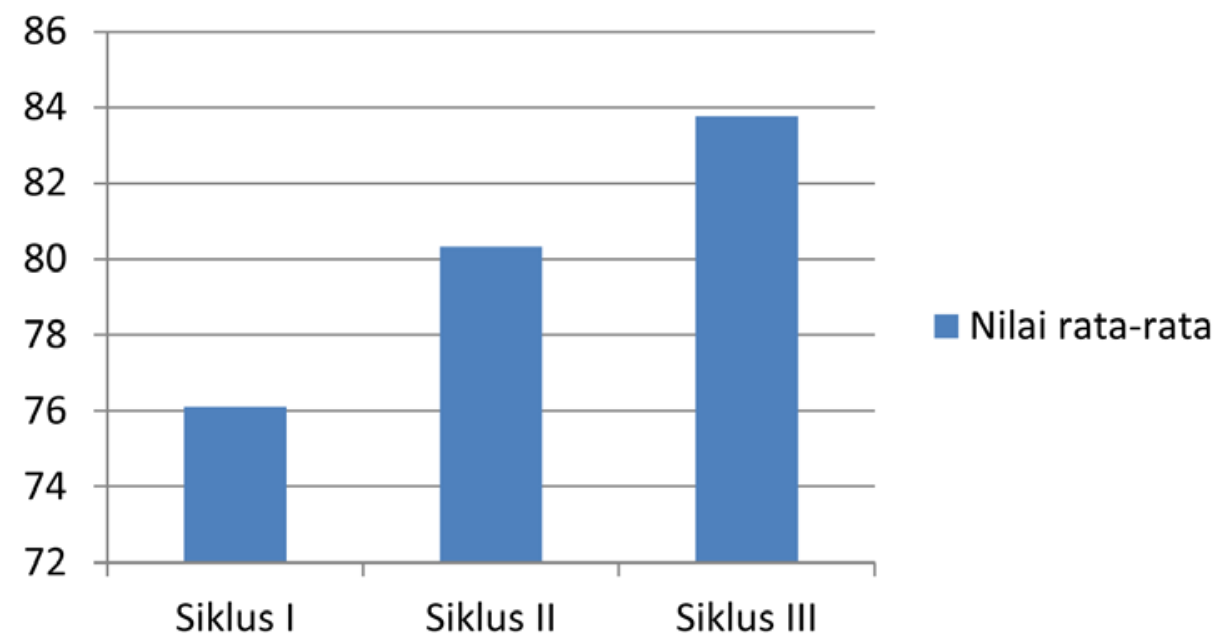

Gambar 2. Prestasi Belajar Merakit Sistem PLC

Pada Siklus I rata-rata nilai siswa 76,10 dilanjutkan pada siklus II dimana siswa ratarata nilai siswa 80,32 dan pada siklus III ratarata nilai siswa 83,77 . Seorang siswa dikatakan tuntas belajar jika menguasai bahan (ketercapaian belajarnya) $\geq 77 \%$. (KKM SMK Negeri 2 Depok Sleman tahun ajaran 20013/2014). Dengan demikian terjadi peningkatan rata-rata nilai siswa dari siklus I ke siklus ke II dan dari siklus ke II ke siklus ke III. Peningkatan ini sekaligus menunjukkan peningkatan yang melampaui KKM yaitu 77.

Berdasarkan uraian hasil penelitian di atas, peneliti dapat mengidentifikasi adanya beberapa hal yang dianggap penting sehubungan dengan pelaksanaan pem-belajaran Merakit
Sistem dengan penerapan model pembelajaran Explicit Instruction. Hal tersebut dibahas berdasarkan logika, kajian teori dan temuantemuan pada penelitian yang relevan. Hasil penelitian yang telah dilaksanakan dalam tiga siklus menunjukkan bahwa penerapan model pembelajaran Explicit Instruction dapat meningkatkan hasil belajar siswa pada mata pelajaran yaitu pembelajaran Merakit Sistem PLC di kelas XII TOI SMK Negeri 2 Depok, Sleman. Hal ini ditunjukkan dengan peningkatan hasil belajar siswa, dimana pada siklus I rata-rata hasil belajar siswa hanya mencapai 70,10 pada siklus II rata-rata nilai siswa 80,32 dan pada siklus III rata-rata nilai siswa 83,77. Hal tersebut disebabkan oleh beberapa 
faktor, antara lain karena kurangnya pemahaman siswa terhadap metode yang diterapkan dan siswa masih
Perhitungan Peningkatan Motivasi Siswa : Hasil Perhitungan rata-rata tiap-tiap siklus : Siklus I : 67 ; Siklus II : 82 ; Siklus III : 85 Disajikan dalam diagram sebagai berikut:

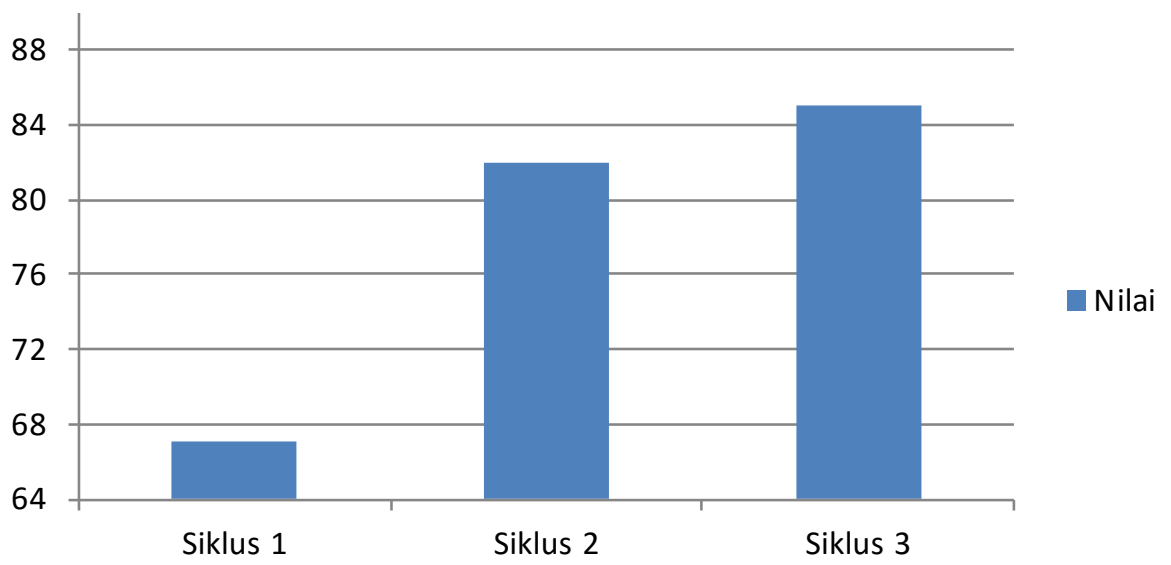

Gambar 6. Diagram Peningkatan Motivasi Siswa

Pada siklus I diperoleh hasil motivasi belajar siswa bernilai 67, siklus II diperoleh nilai 82 dan siklus III diperoleh nilai 85 . Hasil ini menunjukkan bahwa penerapan Explicit Instruction Model pada Siswa SMKN 2 Depok kelas 12 telah meningkatkan motivasi belajar. Pada siklus I siswa cenderung masih bertanyatanya tentang model yang tengah diterapkan oleh guru sehingga masih mendapatkan skor yang relatif kecil yaitu 67. Pada Siklus II siswa telah mampu memahami tentang model pembelajaran yang diterapkan sehingga skornya meningkat menjadi 82 , sedangkan pada siklus III siswa telah menikmati keuntungankeuntungan dai model pembelajaran ekplisit sehingga skornya meningkat menjadi 85. Dengan demikian terjadi peningkatan motivasi belajar siswa yang semula rendah $(<75)$ pada siklus 1 meningkat menjadi tinggi $(>75)$ pada siklus II dan siklus III.

\section{SIMPULAN}

Berdasarkan hasil penelitian tentang penggunaan model pembelajaran explicit instruction dengan media trainer PLC untuk meningkatkan prestasi belajar merakit sistem PLC di SMKN 2 Depok Sleman, dapat ditarik beberapa kesimpulan yaitu

Pembelajaran dengan model Explicit Instruction cocok diterapkan pada pembelajaran praktikum Mata Pelajaran/Standar Kompetensi Merakit Sistem PLC siswa kelas XII-TOI. Dengan demikian dapat dibuat keputusan bahwa hipotesis tindakan diterima artinya siswa dapat memenuhi nilai KKM yang sudah ditetapkan dan siswa mendapatkan nilai yang lebih tinggi dari KKM yang ditetapkan setelah mengguna-kan Model Pembelajaran Explicit Instruction.

Setelah diterapkan model Explicit Instruction nilai Mata Pelajaran / Standar Kompetensi Merakit Sistem PLC siswa kelas XII-TOI lebih tinggi dari sebelum diterapkannya model Explicit Instruction. Pada tindakan siklus I hanya ada 17 orang siswa yang nilainya sudah memenuhi KKM atau sekitar 54,84\% .setelah dilakukan tindakan siklus II ada 29 orang siswa yang nilainya 
sudah memenuhi KKM atau 93,55 \%. Pada tindakan siklus III ada 31 orang siswa yang nilainya sudah memenuhi KKM atau $100 \%$. Dengan hasil tes formatif sebagai berikut maka nilai rata-rata siswa: Siklus I sebesar 76,10 ; Siklus II sebesar 80,32; dan Siklus III sebesar 83,77.

Setelah diterapkan model Explicit Instruction motivasi belajar siswa pada Mata Pelajaran Merakit Sistem PLC siswa kelas XII-TOI lebih tinggi dari sebelum diterapkannya model Explicit Instruction. Dari tiga siklus pembelajaran yang telah dilaksanakan

\section{DAFTAR RUJUKAN}

Arif S. Sadiman. 2003. Media Pendidikan: Pengertian, Pengembangan dan Pemanfaatannya. Jakarta: PT. Raja Grafindo Persada

Mulyasa, E. 2005. Menjadi Guru Profesional: Menciptakan Pembelajaran Kreatif dan Menyenangkan. Bandung: PT Remaja Rosdakarya

Nana S., Ahmad R., dkk .1997. Media Pengajaran (Penggunaan dan Pembauatanya). Bandung: CV. Sinar Baru

Sardiman, A.M. 1992. Interaksi dan Motivasi Belajar Mengajar. Jakarta: CV Rajawali Press dan diadakan pengambilan data yang berupa angket motivasi diperoleh hasil motivasi belajar siswa bernilai 67 pada siklus I yang menggambarkan bahwa motivasi belajar siswa rendah karena nilai yang dihasilkan $<75$. Angket motivasi belajar siswa pada siklus II diperoleh nilai 82 yang menggambarkan bahwa motivasi belajar siswa tinggi karena nilai yang dihasilkan $>75$. Angket motivasi belajar siswa pada siklus III diperoleh nilai 85 yang menggambarkan bahwa motivasi belajar siswa tinggi karena nilai yang dihasilkan $>75$.

Slameto. 1988. Belajar dan Faktor- Faktor yang Mempengaruhinya. Jakarta: Bina Aksara

Sugiyono. 2008. Metode Penelitian Pendidikan Pendekatan Kuantitatif, Kualitatif, dan $H \& D$. Bandung. Alfabeta

Arikunto, Suharsimi. 2008. Dasar-Dasar Evaluasi Pendidikan. Jakarta: Bumi Aksara

Arikunto, Suharsimi. 2002. Prosedur Penelitian Suatu Pendekatan Praktek. Jakarta: Rineka Cipta

Syah, Muhibin. 2002. Psikologi Pendidikan dengan Pendekatan Baru. Bandung: Remaja Rosdakarya 